\title{
SIMBOL "JANTAN POSITIF" DALAM \\ UNGKAPAN MELAYU TENAS EFFENDY \\ DARIPADA GAGASAN KRITIKAN MELAYU \\ S. OTHMAN KELANTAN
}

\section{(“Jantan" as a Positive Symbol in Tenas Effendy's Ungkapan Melayu According to S. Othman Kelantan's Malay Criticism Framework)}

Noor Hasnah Adam*

noor_hasnah_adam@moe.edu.sg

Ministry of Education, Singapore.

Norhayati Ab. Rahman

yati@um.edu.my

Jabatan Sastera, Akademi Pengajian Melayu, Universiti Malaya.

Terbit dalam talian (published online): 1 Januari 2021

Sila rujuk: Noor Hasnah Adam dan Norhayati Ab. Rahman. (2021). Simbol "Jantan Positif" dalam Ungkapan Melayu Tenas Effendy daripada Gagasan Kritikan Melayu S. Othman Kelantan. Melayu: Jurnal Antarabangsa Dunia Melayu, 14(1), 115-140.

\begin{abstract}
Abstrak
Artikel ini membincangkan simbol jantan positif yang terdapat dalam ungkapan Melayu. Ungkapan Melayu untuk kata "jantan" yang terpilih ini terkandung dalam buku Ungkapan Melayu - Pemahaman dan Permasalahannya oleh Tenas Effendy. Ungkapan Melayu merupakan kumpulan puisi lisan. Fokus penulisan hanya pada simbol jantan positif. Perbincangan bersandarkan Gagasan Kritikan Melayu oleh S. Othman Kelantan yang mengandungi 10 gagasan prinsip. Makna siratan simbol jantan dikupas untuk memperlihatkan pemikiran masyarakat Melayu yang menggunakan ungkapan ini. Artikel ini juga mencirikan setiap ciri“jantan positif” yang terakam dalam buku ini. Ungkapan Melayu yang dikaji dapat membongkar budaya pemikiran masyarakatnya secara tersirat, sekali gus menelusuri serta memanfaatkan ilmu pengetahuan daripada khazanah bangsa Melayu ini. Kajian tentang "jantan positif" ini penting untuk menganalisis sudut pandangan dunia
\end{abstract}


MELAYU: JURNAL ANTARABANGSA DUNIA MELAYU JILID 14 BIL. 1 JANUARI 2021

masyarakat Melayu dalam sastera lisan yang disampaikan secara tersurat dan tersirat melalui penggunaan lambang dalam ungkapannya.

Kata kunci: Simbol, jantan, ungkapan Melayu, makna siratan, Gagasan Kritikan Melayu

\begin{abstract}
This paper discusses about the symbol of "jantan" (male dominance) which have positive meanings, found in Malay proverbs by Tenas Effendy. This discussion uses the Framework of Malay Critiques by S. Othman Kelantan, which contains 10 principles. The underlying meanings in the "jantan" symbol will be analyzed to scrutinize the worldview of those who conceptualize these Malay proverbs as well as their association with the negative traits of male dominance. Malay proverbs that have been examined will be able to illuminate the inherent thought patterns of the Malay society, and at the same time, explore their vast knowledge of the world. Research on the Malay "Jantan" is important to analyze the lens in which was viewed by a predominantly oral society, as well as the explicit and implicit meanings of the symbols in Malay proverbs.
\end{abstract}

Keywords: Symbol, male, proverbs, underlying meaning, Malay critiques

\title{
PENDAHULUAN
}

Penggunaan perkataan "jantan" yang dikaitkan dengan binatang dalam ungkapan Melayu sering menimbulkan pertanyaan, mengapa lelaki dipanggil "jantan" tidak lelaki atau pemuda? Hal ini berbeza pula dengan ungkapan Melayu berkenaan wanita, yang dibahagikan kepada lima kategori, iaitu dara, bini, isteri, ibu dan perempuan. Dalam konteks pemahaman masyarakat zaman dahulu, maksud "jantan" sama penerimaannya dengan perkataan "lelaki". Penggunaan istilah "jantan" dalam masyarakat Melayu membawa konotasi makna yang positif dan negatif. Dalam artikel ini hanya membincangkan aspek positifnya. Pada zaman dahulu, gelaran "anak jantan" dibaca dalam konotasi makna positif, iaitu lambang keberanian. Sementara itu, gelaran "bukan anak jantan" pula dianggap sebagai pengecut dan membawa keaiban kepada diri dan keluarga. Oleh itu, banyak watak dalam karya klasik yang menerapkan unsur "kejantanan" dalam diri watak dan perwatakan pahlawan atau hero bagi sesebuah cerita. Walau bagaimanapun perubahan budaya yang berlaku dalam masyarakat pada hari ini, memberikan anjakan makna kepada penerimaan perkataan "jantan". Menurut Tenas Effendy, ungkapan masa hadapan akan berubah simbol, yakni daripada memakai simbol latar yang bersifat alam 
semula jadi, menjadi simbol baharu yang ada di alam moden ini. Hal ini terjadi kerana pengaruh luaran dan dalaman sepanjang perubahan zaman. Pada zaman sekarang, apabila seorang itu digelar "jantan" dapat menimbulkan rasa tidak senang hati pendengarnya kerana gelaran sebegitu dianggap sebagai suatu penghinaan. Tinjauan umum yang dilakukan di media sosial menunjukkan berlaku pertengkaran antara lelaki dan wanita disebabkan kata panggilan seperti "jantan" dan "betina". Situasi ini secara tidak langsung memperlihatkan wujudnya perubahan budaya hidup dalam masyarakat Melayu, khususnya terhadap penerimaan konsep "jantan”. Sebagai contoh, apabila ungkapan Jantan Bibir dan ungkapan Jantan Borak dikongsi di media sosial Facebook pada 6 hb Februari 2015, terdapat maklum balas daripada lelaki yang berasa panas hati dan menganggap bahawa kata-kata tersebut sebagai suatu penghinaan terhadap lelaki. ${ }^{1}$

Ungkapan Melayu merupakan salah suatu bentuk puisi Melayu tradisional yang diungkapkan secara lisan dan kaya dengan nilai kesusasteraan. Menurut Muhammad Haji Salleh (2006: 95-107), ungkapan Melayu yang terhasil pada zaman sastera lisan, sering dimulakan dengan pemerian, penjelasan mudah dan bahasa dasar. Bahasa yang digunakan pada dasarnya ialah bahasa terpilih atau tersaring dan kemudian diwarnakan. Ungkapannya bukan hanya mengandungi falsafah kehidupan masyarakatnya, tetapi juga sarat dengan makna dan nilai yang berfungsi sebagai penjelasan. Dengan demikian, sesebuah ungkapan tunggal akan bertambah dengan ungkapan penjelasannya, sehingga menjadi untaian ungkapan yang kadangkala cukup panjang. Cara ini disebut, "menukuk menambah, menampal menyulam, supaya yang tersirat nampak tersurat, yang terlindung dapat tersingkap, yang tersembunyi dapat didedahkan". Selain menjadi bahan pengajaran dan nasihat kepada generasi muda, ungkapan Melayu mempunyai banyak lambang dan makna yang berlapis, sekali gus memaparkan pemikiran serta pandangan hidup manusia Melayu. Melalui kajian S. Othman Kelantan (1997) terhadap satira sehingga terbitnya Gagasan Kritikan Melayu, maka dapat dinilai imej, lambang, peristiwa, perilaku, kebatinan dan kerohanian dalam teks yang memberikan makna tersirat, kerana segalanya berkait rapat dengan alam sekitar, budaya dan pemikiran manusia Melayu.

Artikel ini membincangkan makna tersirat perkataan "jantan" yang pernah wujud dalam cerita sastera lisan masyarakat Melayu dan telah dibukukan pada tahun 2012 dengan tajuk Ungkapan Melayu-Pemahaman dan Permasalahannya (selepas ini akan diringkaskan sebagai Ungkapan Melayu) oleh Tenas Effendy bagi memperlihatkan unsur pemikiran masyarakat dan khazanah ilmu bangsa Melayu yang terkandung di dalamnya. Segala inti pati khazanah ilmu tersebut sepatutnya dimiliki dan dimanfaatkan oleh lelaki Melayu khususnya, agar mereka menjadi 
MELAYU: JURNAL ANTARABANGSA DUNIA MELAYU JILID 14 BIL. 1 JANUARI 2021

"orang" dan mampu menjadi "khalifah" bagi memimpin masyarakatnya. Kajian tentang simbol "jantan" ini penting bagi menganalisis pandangan dunia (worldview) masyarakat Melayu lama berdasarkan maksud tersurat dan tersirat dalam ungkapan Melayu.

Pendekatan yang akan digunakan bagi tujuan penganalisisan data kajian terpilih ialah Gagasan Kritikan Melayu oleh S. Othman Kelantan (1998). Gagasan Kritikan Melayu mempunyai sepuluh prinsip utama.

1. Memberikan tumpuan terhadap teks memandangkan teks menjadi alat untuk menimbulkan kritikan.

2. Menggunakan lambang, imej, peristiwa, cerita, alegori dan sebagainya, kerana melalui penggunaan setiap unsur tersebut yang amat rapat dengan alam dan persekitaran orang Melayu itu dapat diwujudkan kritikan secara tersirat.

3. Memberikan tumpuan terhadap perilaku atau tindakan watak tertentu yang menyebabkan berlakunya sesuatu kejadian atau peristiwa yang luar biasa, supaya dapat menyampaikan pengajaran atau kritikan tertentu.

4. Menimbulkan kesedaran melalui sesuatu kejadian dalam cerita, sama ada melalui lambang atau imej alamiah, atau manusia.

5. Harus berupaya menyumbangkan ilmu kerana setiap teks sastera Melayu (klasik terutamanya) menyerap budaya dan cita rasa Islam yang membawa kepada pemikiran akliah, bukannya seni semata-mata.

6. Membawa contoh yang lebih baik, dengan dasar kritikan bertunjangkan ilmu, mengemukakan hujah atau alasan yang lebih baik, sesuai dengan anjuran agama Islam.

7. Kritikan menyentuh soal kebatinan atau kerohanian dalam teks sastera bagi memaparkan budaya Melayu.

8. Kritikan perlu juga meneliti imaginasi, iaitu bagaimana sesuatu imaginasi itu dianggap benar dan diadun dengan imaginasi kreatif.

9. Kritikan bersifat intelektual dan sindiran yang dikemukakan dalam karya memperlihatkan sifat intelektual pengarangnya.

10. Kritikan mementingkan pengucapan bahasa yang halus dan penuh estetika. 


\section{ANALISIS DAN DAPATAN KAJIAN}

Pada umumnya, Ungkapan Melayu memperlihatkan penggunaan simbol "jantan" yang boleh dibahagikan kepada dua kategori utama, iaitu kategori "positif" dan "negatif". Daripada semua ungkapan Melayu yang berhubung dengan perkataan jantan dalam koleksi ini, didapati sejumlah 52 daripada 178 simbol jantan yang bawa maksud positif. Semua simbol tersebut merakamkan cara orang Melayu menghayati hidup yang dianggap unggul dengan unsur yang terkandung dalam sudut pandang (weltanschauung) dan budaya alam bangsa Melayu. Mereka melihat alam tabii sebagai penuh makna, simbolisme dalam gurindam dan syair. Mereka juga hidup berteraskan prinsip harmoni dengan alam, yang dihayati melalui ritual dan manifestasi kebudayaan. Manifestasi kebudayaan tersebut biasanya berpandukan semiotik tabii dan kosmologi kebudayaan yang diwarisi dan dimantapkan daripada satu generasi kepada satu generasi. Prinsip kedua Gagasan Kritikan Melayu banyak tertumpu pada penggunaan lambang, imej, peristiwa, cerita, alegori dan sebagainya (Hairudin, 2001). Alegori ialah majas yang menjelaskan maksud tanpa secara harfiah, yang lazimnya merujuk penggunaan retorik, namun tidak semestinya ditunjukkan melalui bahasa semata-mata. Misalnya alegori dipamerkan melalui lukisan, pahatan,

Jadual 1 Kategori Ungkapan Melayu jantan positif.

\begin{tabular}{|c|c|c|c|c|c|c|}
\hline Bil. & Benda & Perilaku & \multicolumn{2}{|c|}{ Konsep } & \multicolumn{2}{c|}{ Sifat } \\
\hline 1 & cikar & acu & aduan & Abadi & adil & cerdas \\
\hline 2 & santan & ingat & akhlak & Bawaan & baik & elok \\
\hline 3 & bara & awas & adat & Baka & bijak & halus \\
\hline 4 & cedak & padan & contoh & & alim & sabar \\
\hline 5 & kawan & giat & juara & & gagah & yakin \\
\hline 6 & ayah & & kampung & & jinak & laku \\
\hline 7 & pasak & & patut & & licin & lurus \\
\hline 8 & betik & & tokoh & & liat & lasak \\
\hline 9 & tulang & & sabungan & & tabah & cerdik \\
\hline 10 & \multicolumn{7}{|}{} & pilihan & & lincah & faham \\
\hline 11 & & berisi & & handal & berani \\
\hline 12 & & & & & iba & cergas \\
\hline & 9 & 5 & 14 & & 24 \\
\hline
\end{tabular}


dan sebagainya. Dengan sendirinya wujud kritikan dalam kesusasteraan yang tertumpu pada lambang, imej, peristiwa, cerita, alegori dan sebagainya, yang amat rapat dengan alam persekitaran orang Melayu, untuk mendapatkan makna atau pengertian yang tersirat. Berdasarkan teks Ungkapan Melayu didapati penggunaan simbol "jantan" bagi kategori "positif" dapat dibahagikan kepada empat golongan simbol, iaitu "benda", "perilaku", "konsep" dan "sifat" seperti dalam Jadual 1.

\section{Simbol Jantan Positif dalam Kategori Benda}

Simbol jantan positif berkaitan dengan lambang benda dalam lingkungan masyarakat Melayu ini merupakan kata nama am, daripada benda zahir sehinggalah kepada kata nama gelaran. Benda zahir merupakan benda yang lazim digunakan oleh masyarakat Melayu. Begitu juga dengan gelaran yang biasa digunakan dalam kesantunan masyarakat Melayu. Jadual 1 memperlihatkan kategori "benda" terdiri daripada perkataan "jantan cikar", "jantan santan", "jantan bara”, "jantan kawan”, "jantan ayah", "jantan pasak", "jantan betik", "jantan tulang" dan "jantan cedak". Jantan yang disimbolkan dengan benda maujud tersebut berkait rapat dengan sifat benda itu sendiri, yang maksudnya menggambarkan alam sekitar, kepercayaan, serta budaya kehidupan masyarakat. Dalam ungkapan Melayu tentang jantan positif kategori benda, terdapat lambang daripada alam semula jadi seperti buah-buahan tempatan untuk mengaitkan lambang jantan, iaitu "jantan santan" dan "jantan betik", bahan makanan (unsur alam) yang banyak tumbuh di alam Melayu.

Penggunaan lambang, imej, peristiwa, cerita, alegori dan sebagainya seperti ini ditegaskan oleh Gagasan Kritikan Melayu yang melihat setiap unsur diaplikasikan dalam karya sastera adalah amat rapat dengan alam persekitaran orang Melayu sehingga penggunaannya berupaya mewujudkan kritikan secara tersirat terhadap masyarakat. Menurut Tenas Effendy (1994), bahasa bukan sahaja bentuk untuk manusia mengungkapkan cita rasanya, tetapi juga menunjukkan cara manusia berfikir. Ungkapan "alam terkembang jadikan guru" bererti membaca ayat al-kawn al-Quran, merenung tanda-tanda kebesaran Tuhan pada alam yakni cakerawala, flora dan faunanya yang serba serasi dan harmonis. Alam pada hakikatnya adalah juga sebuah kitab yang padat dengan ayat (tanda-tanda kebesaran Tuhan). Iktibar daripada alam itulah yang membentuk sebahagian daripada nilai-nilai hidup Melayu seperti yang tercermin dalam peribahasa dan ungkapan-ungkapan tradisional.

Santan misalnya, merupakan bahan keperluan asas dan penting dalam kegunaan pelbagai jenis masakan tradisi masyarakat Melayu. Masakan kuih-muih atau laukpauk Melayu tidak akan menjadi sedap tanpa santan atau kekurangan santan. Dalam 
konteks ini, santan bukan hanya berperanan sebagai penentu kelazatan rasa sesuatu masakan, tetapi juga untuk menilai sifat seseorang tukang masak, sama ada pemurah dan ikhlas atau kedekut. Gambaran tersebut diperlihatkan dalam teks Ungkapan Melayu melalui contoh seperti berikut:

\author{
Yang disebut "jantan santan": \\ keturunan elok, dada beriman \\ ilmu dituntut ia amalkan \\ pantang dan larang ia ikutkan \\ kasihnya tidak memilih kawan \\ adilnya tidak memandang kekayaan \\ hidupnya menjadi suri teladan \\ petuahnya menjadi tempat pegangan \\ hidup setia mati beriman \\ kepada mengalir rahmat Tuhan
}

Bagi lelaki yang digelar "jantan santan" dalam contoh ungkapan di atas merujuk lelaki yang berketurunan baik, beriman dan mengamalkan ilmu yang dipelajari dalam kehidupan. "Jantan santan" menjadi simbol bagi lelaki yang akur dan mematuhi segala pantang larang, memiliki sifat kasih sayang terhadap kawan-kawan tanpa memilih kedudukan, serta berlaku adil dan tidak memandang kekayaan. Lelaki sebegini hidupnya sentiasa menjadi suri teladan dengan segala petunjuk dan petua akan dijadikan pegangan. Gambaran hidup lelaki seperti ini dikatakan penuh setia dan matinya pula dalam keimanan serta mendapat rahmat Tuhan. Santan banyak kegunaannya dalam masakan dan kuih-muih masyarakat Melayu. Oleh itu, simbol "jantan santan" menjadi simbol jantan positif dan wajar dicontohi oleh anggota masyarakat.

Betik pula merupakan sejenis buah yang banyak ditanam di alam Melayu, yang digemari untuk dimakan kerana khasiatnya. Menurut Dr. Rizal Abu Bakar (2019, Jun) dalam majalah Mingguan Wanita bertarikh 19 Jun 2019, The World Health Organisation (WHO) telah menobatkan buah betik sebagai raja buah kerana khasiatnya yang luar biasa. Selain menjadi sumber makanan yang murah dan mudah didapati, buah betik juga mengandungi khasiat yang tinggi dengan kandungan 
hampir semua zat makanan yang diperlukan bagi kesihatan tubuh. Antara khasiatnya termasuklah dapat mencegah sembelit, mencegah kulit berjerawat, mencegah terjadinya batu dalam pundi-pundi kencing dan mengubati sakit-sakit otot. Pucuk daun betik digunakan secara tradisional oleh para dukun Melayu dalam memberikan rawatan untuk penyakit yang berkaitan dengan darah (seperti denggi) yang berpunca daripada nyamuk. Oleh itu, pokok betik ditanam di halaman hampir setiap rumah di kampung. Berdasarkan data ungkapan Melayu yang dikaji menunjukkan subjek "jantan betik", yang dipaparkan dalam karya sastera Melayu tradisional, mempunyai kelebihan tersendiri. Contohnya seperti ungkapan "jantan Betik" yang berikut:

Yang disebut "jantan betik"

rupa tampan budi pun baik

(2012: 381-382)

Petikan ucapan di atas memperlihatkan penggunaan istilah "jantan betik" merujuk lelaki yang tampan dan baik serta gemar berbakti kepada masyarakatnya. Oleh itu, penggunaan "jantan betik" dalam Ungkapan Melayu merupakan simbol atau perlambangan bagi sifat dan sikap lelaki yang baik serta berguna kepada masyarakatnya. Oleh yang demikian, penggunaan kata "santan" dan "betik" dalam Ungkapan Melayu dijadikan sebagai lambang pemikiran dan tanggapan masyarakat dengan makna positif terhadap lelaki yang bergelar "Jantan Santan" dan "Jantan Betik".

Perkataan "Cikar" pula merupakan pedati atau kereta roda tradisional yang menggunakan tenaga lembu, sapi atau kerbau untuk menggerakkannya. Pada zaman sebelum teknologi, kenderaan berenjin, masyarakat banyak bergantung pada cikar untuk bergerak dari satu tempat ke satu tempat yang lain. Cikar umpama teksi pada hari ini. Pengendalian cikar perlu dilakukan dengan berhati-hati kerana kenderaan cikar menggunakan tenaga haiwan yang tindak tanduknya sukar diramal. Ungkapan Melayu menggunakan simbol "jantan Cikar" bagi menerangkan lelaki yang sangat berhati-hati ketika membuat sesuatu pekerjaan dan tindakan, mempunyai fikiran yang tajam dan hati yang baik seperti simbol "Jantan Cikar" dalam ungkapan berikut:

Yang disebut "jantan cikar":

fikiran tajam, hati pun besar 
memikul beban tiada ingkar

bekerja tangkas lurus dan benar

bercakap tidak pernah mengasar

menghadapi masalah tiada gentar

menjalankan tugas siap sebentar

namanya baik tiada tercemar

kepada dirinya orang bersandar

(2012: 373)

Berdasarkan ungkapan di atas, lelaki yang digelar "jantan Cikar" dalam Ungkapan Melayu digambarkan sebagai seseorang yang tidak pernah ingkar atau merungut terhadap beban yang dipikulnya, malah berani menghadapi masalah tanpa perasaan gentar. Pekerjaan dilakukannya dengan tangkas dan cepat, serta dengan benar dan jujur. Percakapannya tidak pernah kasar, namanya tidak pernah tercemar bahkan menjadi rujukan oleh masyarakat. Frasa "orang bersandar" dalam petikan di atas bermaksud dirinya menjadi harapan keluarga dan masyarakat dan diharapkan untuk membantu serta melindungi masyarakatnya. Seperti cikar yang menjadi keperluan mustahak masyarakat pada zaman tersebut, sangat lasak menanggung segala tanggungjawab, begitu juga dengan sifat "jantan Cikar" yang perlu ada dalam diri lelaki, seperti yang digambarkan dalam Ungkapan Melayu.

Perbincangan di atas memperlihatkan kesesuaian prinsip kedua Gagasan Kritikan Melayu digunakan bagi tujuan menghuraikan makna teks dalam Ungkapan Melayu, kerana prinsip tersebut menekankan peri pentingnya penggunaan lambang, imej, peristiwa, cerita, alegori dan sebagainya sebagai satu cara atau kaedah menegur, menyaran atau mengkritik masyarakat pada zaman tersebut. Melalui penggunaan unsur yang rapat dengan alam persekitaran orang Melayu akan dapat mewujudkan kritikan secara tersirat. Oleh itu, penggunaan lambang santan, betik dan cikar dalam Ungkapan Melayu di atas memperlihatkan makna tersirat dalam pemikiran Melayu, khususnya berhubung dengan ciri-ciri positif seseorang lelaki pada masa itu. Mereka tidak menerangkan sifat positif yang diingini dalam masyarakat secara langsung, sebaliknya menggambarkannya melalui penggunaan simbol yang membayangkan ketinggian pemikiran masyarakat yang tercermin dalam kias ibarat, tamsil dan lambang. 


\section{Simbol Positif Jantan dalam Kategori Perilaku}

Prinsip ketiga dalam Gagasan Kritikan Melayu memberikan tumpuan terhadap perilaku. Dalam karya sastera tradisional, banyak perilaku atau tindakan watak tertentu yang menyebabkan berlakunya sesuatu kejadian atau peristiwa yang luar biasa. Kajian terhadap perilaku menunjukkan ada unsur sebab dan akibat yang dikarang supaya dapat menyampaikan pengajaran atau kritikan. Perilaku merujuk tingkah laku atau perlakuan yang terpapar hasil daripada tindakan seseorang. Dalam Jadual 1, simbol jantan positif yang mempunyai kaitan dengan lambang perilaku seseorang termasuklah simbol "jantan ingat", "jantan awas", "jantan padan”, “jantan acu" dan "jantan giat". Contoh penggunaan simbol "jantan padan" dalam Ungkapan Melayu dapat dilihat seperti petikan yang berikut:

Yang disebut "jantan padan":

lahir dan batin ia sepadan

Kepala berisi dada beriman

Berani tidak memilih lawan

Sesuai cakap dengan perbuatan

Orang kasih, musuh pun segan

Sampai mati jadi teladan

(2012: 373)

Penggunaan simbol "jantan Padan" dalam Ungkapan Melayu di atas menggambarkan lelaki yang memiliki sifat lahir dan batin yang sepadan. Lelaki seperti ini digambarkan tidak memilih lawan dan berani menghadapi sesiapa sahaja. Kepalanya dikatakan berisi dan dadanya beriman. Dengan perkataan lain, lelaki yang digelar sebagai "jantan padan" bukan hanya pandai bercakap atau "cakap tidak serupa bikin", tetapi mereka melakukan perbuatan dan bertindak sesuai dengan apaapa yang diutarakan. Lelaki sebegini dikatakan akan dikasihi kawan dan disegani musuhnya. Ungkapan Melayu tentang "jantan padan”, seperti juga kebanyakan ungkapan lain tentang jantan, akan turut mengaitkan soal kepercayaan dalam agama Islam, iaitu tentang dosa pahala, balasan perbuatan semasa hidup dan balasan perbuatan selepas mati. Moral yang ingin disampaikan ialah "yang baik dibalas baik, yang buruk dibalas buruk". Dalam konteks ini, simbol jantan positif dalam kategori perilaku ini digunakan untuk memaparkan tentang perilaku watak atau 
perwatakan dalam sastera tradisional, khususnya dalam ungkapan Melayu seperti yang ditekankan dalam prinsip Gagasan Kritikan Melayu.

Dalam kategori Ungkapan Melayu tentang "jantan" kategori positif yang dipaparkan dalam Jadual 1, terdapat penggunaan simbol "jantan ingat" yang menerangkan tentang perilaku atau tindakan lelaki yang perlu sentiasa beringat tentang kehidupan selepas mati. Selain itu, simbol "jantan ingat" yang dipaparkan di sini juga menggambarkan lelaki yang rajin menuntut ilmu yang bermanfaat, rajin beramal dan mengerjakan ibadat dan sentiasa memikul beban yang berat demi kepentingan masyarakatnya, seperti yang tertera dalam ungkapan "jantan Ingat" yang berikut:

Yang disebut "jantan ingat":

hidup matinya di dalam ingat

ingat menuntut ilmu bermanfaat

ingat beramal mengerjakan ibadat

ingat memikul beban yang berat

ingat menolong sesama umat

ingat berhitung pandai menghemat

selamatlah hidup dunia akhirat

(2012: 75)

Berdasarkan ungkapan di atas, gambaran tentang "jantan ingat" dikaitkan dengan perwatakan atau perilaku lelaki yang sentiasa bersiap sedia untuk menghadapi masa susah. Lelaki sebegini dipaparkan sebagai pandai mempersiapkan diri dalam sebarang keadaan di dunia, dan juga mempersiapkan diri untuk bekalan akhirat. Oleh itu, hidup lelaki seperti ini dikatakan akan selamat di dunia dan di akhirat. Pemaparan perilaku sebegini menjadikan lelaki yang disimbolkan sebagai "jantan Ingat" sebagai lelaki yang dipandang tinggi dan mulia kedudukannya dalam kalangan masyarakat. Gambaran perilaku watak atau perwatakan dalam teks sastera tradisional seumpama ini adalah selaras dengan penekanan prinsip Gagasan Kritikan Melayu.

Penggunaan simbol seterusnya yang disenaraikan dalam Jadual 1 ialah "jantan giat", iaitu merujuk lelaki yang mempunyai hati bersih dan akal sihat. Kehidupannya dipenuhi dengan kegiatan dan berbuat amal serta rajin bekerja melakukan pekerjaan. Lelaki seperti ini digambarkan sebagai pandai membawa diri dalam hidup bermasyarakat. Perilakunya juga diperlihatkan sebagai seorang yang tidak suka mengumpat. Dengan perilaku positif yang sedemikian, lelaki seperti ini disukai oleh 
kawan-kawan, dan hidupnya dikatakan aman sentosa di dunia dan di akhirat, seperti yang digambarkan dalam Ungkapan Melayu tentang "jantan giat" seperti berikut:

Yang disebut "jantan giat":

hati bersih akal pun sihat

bekerja rajin, beramal kuat

hidup bermasyarakat ia bergiat

berpenat berletih tiada mengumpat

bersaudara rukun, sahabat mendekat

hidup sentosa dunia akhirat

Pelukisan tentang perilaku lelaki yang disimbolkan melalui "jantan giat" di atas juga memperlihatkan perkaitan atau keselarasannya dengan penekanan prinsip Gagasan Kritikan Melayu. Malah didapati penggunaan simbol "jantan giat" juga melambangkan perwatakan atau perilaku lelaki positif yang disenangi dan dialualukan, serta dijadikan sebagai contoh lelaki yang baik dalam kalangan anggota masyarakat Melayu.

Gambaran perilaku watak atau perwatakan dalam sastera tradisional yang dikemukakan dalam prinsip Gagasan Kritikan Melayu juga ditemui pada penggunaan simbol "jantan acu" yang dicipta bagi melambangkan lelaki contoh atau tempat membuat rujukan. Dalam karya sastera tradisional, masyarakat digambarkan sering merujuk lelaki yang digambarkan sebagai "jantan acu" untuk mendapatkan penjelasan tentang sesuatu ilmu. Ungkapan Melayu menggambarkan perilaku "jantan acu” seperti berikut;

Yang disebut "jantan acu":

jantan tempat orang mengacu

mulia budi dan elok laku

tahu menjaga aib dan malu

tahu bekerja memanfaatkan waktu

amalan banyak, dada berilmu

sahabat banyak, menjauh seteru 
Petikan contoh tersebut memperlihatkan perilaku lelaki yang disimbolkan melalui "jantan acu", yang dikatakan berilmu dan berpekerti mulia serta elok pula tingkah lakunya. Paling penting, "jantan acu" dilukiskan sebagai lelaki yang pandai menjaga maruah dan kehormatan diri serta keluarga. Sebagai orang yang berilmu, lelaki berperilaku seperti ini sangat dihormati, dimuliakan dan kedudukannya tinggi dalam masyarakat.

Selain itu, perkataan "jantan awas" yang turut disenaraikan dalam Jadual 1 pula melambangkan perilaku seseorang lelaki yang sentiasa berjaga-jaga dengan keadaan sekitarnya. Lelaki seperti ini digambarkan mempunyai mata dan telinga yang peka dan sentiasa bersiap sedia. Orangnya digambarkan sebagai tahan lasak sama ada berhujan atau berpanas, dan sanggup menempuh apa-apa sahaja cabaran walaupun terpaksa berkorban. Lelaki sebegini juga digambarkan mempunyai akal yang panjang dan berfikiran cerdas. Lelaki yang digelar "jantan awas" menemui kepuasan dalam kehidupan dan akhir hidupnya, seperti ungkapan "jantan awas" yang berikut:

Yang disebut "jantan awas":

telinga nyaring mata pun awas

tahan berhujan tahan berpanas

akal panjang fikiran cerdas

hidup dan mati hatinya puas

(2012: 370)

Menurut S. Othman Kelantan (1998: 54) dalam kritikan seperti yang ditemui dalam teks asas, banyak tindakan yang diambil oleh watak tertentu yang menghasilkan suatu kejadian yang luar biasa. Oleh itu, dalam kritikan kesusasteraan, perkara ini menjadi satu bahagian yang penting kerana memperlihatkan kemahuan, cita-cita, aspirasi rakyat terbanyak, yang juga merupakan wawasan orang Melayu. Kategori jantan positif perilaku yang dibincangkan di atas memperlihatkan aspirasi masyarakat untuk mewujudkan perlakuan yang perlu ada dan sesuai diterima oleh masyarakat.

\section{Simbol Jantan Positif dalam Kategori Konsep}

Simbol jantan positif yang berkaitan dengan lambang dengan konsep adalah seperti yang tersenarai dalam Jadual 1, iaitu "jantan berisi", "jantan aduan", "jantan akhlak", "jantan adat", "jantan contoh", "jantan juara", "jantan kampung", "jantan patut", "jantan tokoh", "jantan sabungan", "jantan pilihan", "jantan baka", "jantan bawaan" 
dan “jantan abadi”. Konsep "jantan positif” ini juga dapat dipadankan dengan "ayam sabungan". Perkataan "ayam sabungan" misalnya berkaitan dengan amalan tradisi masyarakat Melayu yang gemar menyabung ayam. Ayam sabungan merupakan aktiviti sosial masyarakat pada zaman dahulu. Konsep juara pada seseorang lelaki itu umpama ayam sabung, seperti yang terdapat dalam penggunaan simbol "jantan aduan", "jantan juara", "jantan kampung", "jantan tokoh", "jantan sabungan” dan "jantan pilihan". Konsep "jantan aduan" misalnya, menjelaskan bahawa "aduan" itu bermaksud "yang dibuat lawan atau yang dibuat laga":

Yang disebut "jantan aduan":

dada berisi, rupa pun tampan

gagah berani jadi andalan

berjuang tidak memilih lawan

bekerja tidak banyak kebelan

berbudi tidak memilih lawan

namanya harum jadi sebutan

(2012: 369)

Berdasarkan ungkapan di atas, menunjukkan pemilihan ayam yang dibuat laga. Ayam yang lahir daripada baka yang baik dan keadaan fizikalnya yang sesuai dipilih untuk dijadikan ayam sabungan. Bagi tujuan tersebut, ayam akan dijaga dengan baik, bermula daripada penjagaan makanannya sehinggalah kepada rawatan dan penjagaan, seperti dalam pembayang pantun warisan ini:

Ayam sabung jangan dikasi

Kalau dikasi jadi mudarat

Diamnya ubi diam berisi

Diamnya penggali berkarat

(Muhammad Ariff, 2004: 102)

Perkataan "dikasi” bermaksud dikembiri. Ungkapan di atas menjelaskan agar ayam sabung jangan dikembiri kerana perbuatan tersebut akan membawa mudarat kepada kesihatan ayam tersebut. Ayam yang dikembiri tidak dapat bersabung lagi kerana menjadi lemah dan akan mengalami kekalahan teruk. Rawatan dan penjagaan ayam 
sabung dianggap penting dan hanya ayam terpilih sahaja yang akan dijadikan ayam sabung. Gambaran tentang ayam terpilih itu pula digambarkan melalui penggunaan konsep "jantan pilihan" seperti dalam contoh petikan di bawah:

$$
\begin{aligned}
& \text { Yang disebut "jantan pilihan": } \\
& \text { lahir dan batin jadi teladan } \\
& \text { budi mulia perangai sopan } \\
& \text { dada lapang sarat beriman } \\
& \text { berani tidak membilang lawan } \\
& \text { setianya teguh rela berkorban } \\
& \text { hidup dan mati jadi ikutan }
\end{aligned}
$$

(2012: 102)

Selain itu, ayam sabungan memang dibela dan dirawat khas untuk tujuan lagaan oleh tuannya. Malah tuannya akan bertaruh harta benda untuk tujuan perlagaan tersebut. Konsep "ayam sabungan" sememangnya ayam aduan yang berani mati dan tidak takut berlawan. Ayam laga akan rosak badannya ketika tua jika terlalu banyak kali berlaga. Malangnya, apabila sudah tidak kuat dan tua, jasanya tidak lagi dipandang oleh masyarakat dan dirinya bakal menjadi korban kerana sudah tidak berguna lagi. Begitulah juga makna tersirat daripada konsep "jantan sabungan" yang berjasa besar kerana keberanian dan kesetiaan tetapi tidak dihargai ketika tua seperti contoh yang berikut:

Yang disebut "jantan sabungan":

jantan menjadi ayam aduan

Hati berani badan menahan

Pantang sekali dicabar lawan

Sesudah tua rosaklah badan

Salah langkah menjadi korban

(2012: 399)

Pada umumnya, kepentingan penggunaan simbol ayam pada masyarakat Melayu tradisional (khususnya dalam konteks masyarakat Melayu Riau) sehingga 
sesetengah anggota masyarakat sanggup mempertaruhkan kampung halaman dalam sesuatu pertandingan laga ayam. Contohnya dapat dilihat dalam cerita rakyat Pak Kaduk, yang digambarkan sebagai "menang sorak, kampung tergadai". Lazimnya ayam yang menang akan menjadi buah mulut dan kebanggaan orang kampung serta sentiasa disanjung tinggi dalam kalangan masyarakat pada ketika itu. Demikianlah makna siratan "jantan kampung” seperti yang digambarkan dalam ungkapan berikut:

Yang disebut "jantan kampung":

menjadi kebanggaan orang sekampung

tahu diri, sadar kan untung

hidup sederhana pantang menyombong

hati ikhlas, suka menolong

di dunia sentosa, di akhirat beruntung

namanya masyhur di teluk dan tanjung

(2012: 375)

Berdasarkan cerita sastera rakyat lisan Pak Kaduk oleh Amril (2000), Pak Kaduk telah diminta menukar ayamnya dengan ayam milik raja. Pak Kaduk telah bersetuju untuk menukarkan ayamnya dengan ayam milik raja. Lalu beliau pulang ke rumah dan menukar baju yang diperbuat daripada kertas. Dalam penyabungan tersebut ayamnya yang telah ditukar dengan raja telah memenangi perlawanan tersebut. Pak Kaduk menjerit kesukaan kerana terlupa bahawa ayamnya telah menjadi hak raja. Perbuatannya yang melompat dan bersorak kesukaan sehingga menyebabkan baju kertasnya menjadi koyak rabak, dan menampakkan punggungnya di hadapan raja. Orang ramai bersorak mengatakan Pak Kaduk gila. Yang sebenarnya ayam Pak Kaduk telah kalah dan dia kehilangan kampung halaman dan anak isteri yang dipertaruhkan dalam perlagaan ayam tersebut. Namun begitu, sekiranya dihayati dengan lebih cermat, sebenarnya Pak Kaduk tidak gila. Pak Kaduk sedar bahawa Pak Kaduk akan kalah dan kehilangan segala-galanya dalam pertandingan sabung ayam itu. Pak Kaduk yakin ayam asalnya sangat hebat dan boleh mengalahkan ayam raja. Namun demikian, sebagai rakyat biasa, apalah dayanya untuk menghalang kehendak raja? Justeru Pak Kaduk sengaja memakai baju kertas hingga koyak kerana itulah sahaja cara untuknya membalas dendam dengan menghina raja, tanpa dihukum bunuh. Hal yang dilakukan oleh Pak Kaduk merupakan suatu refleksi adat Melayu 
"pantang derhaka kepada Raja". Oleh itu, dalam konteks ini Pak Kaduk menjadi simbol kepada konsep "jantan adat" seperti ungkapan berikut;

Yang disebut "jantan adat":

taat setia memegang adat

iman teguh, beramal kuat

nama terpuji, beramal kuat

sampai mati orang mengingat

(2012: 369)

Melalui mesej cerita di atas memperlihatkan Pak Kaduk yang masih lagi memegang kuat adat Melayu, iaitu pantang anak Melayu menderhaka kepada raja walaupun raja telah menganiayai dirinya. Dalam konteks ini, Pak Kaduk dipaparkan sebagai seorang lelaki (rakyat) yang baik dan patuh kepada pemimpin (raja). Dia menuruti kehendak raja yang tidak munasabah tersebut. Pak Kaduk menggunakan cara halus sebagai respons atas tindakan raja dan kedudukannya sebagai rakyat tetap terpelihara dalam lingkungan adat masyarakat walaupun Pak Kaduk tidak berbaju di hadapan raja. Begitu juga dengan makna siratan daripada konsep "jantan akhlak" yang digambarkan berikut:

Yang disebut "jantan akhlak":

hati beriman sempurna akhlak

memikul beban pantang mengelak

berilmu duduk, berbudi tegak

jasanya besar tuah pun nampak

(2012: 370)

Dalam konteks yang sama, walaupun Pak Kaduk telah memalukan dirinya sendiri, namun disebabkan perlakuan Pak Kaduk sebelumnya dianggap sebagai seorang lelaki (rakyat) yang taat maka perbuatannya tersebut tetap dianggap sebagai patut. Walaupun menghadapi lawan yang "luar biasa", iaitu seorang Raja, Pak Kaduk tetap meneruskan langkahnya, pantang berundur dan tidak berasa takut. Oleh yang demikian, gambaran sikap beliau tersebut dikaitkan dengan konsep "jantan patut" seperti tergambar pada ungkapan yang berikut: 
MELAYU: JURNAL ANTARABANGSA DUNIA MELAYU JILID 14 BIL. 1 JANUARI 2021

Yang disebut "jantan patut":

iman teguh sikap pun patut

Ilmunya banyak rajin menuntut

Menghadapi lawan berpantang surut

Menempuh bahaya tak pernah takut

(2012: 397)

Petikan ungkapan di atas merupakan kategori Ungkapan Melayu tentang "jantan" kategori positif yang berkaitan dengan konsep. Setiap simbol jantan yang dijelaskan membawa konsep yang mewakili cara bertindak dan berfikir anggota masyarakat Melayu tradisional ketika berdepan dengan keadaan dan cabaran di sekeliling mereka. Contohnya seperti cara dan kaedah Pak Kaduk berdepan dengan cabaran berbentuk "arahan" atau "titah perintah" seorang Raja. Semua paparan tersebut membawa siratan makna tersendiri sebagai satu kaedah kritikan Melayu dalam sastera tradisional.

Kesimpulannya, konsep ayam sabungan diangkat menjadi simbol "jantan positif' yang terkenal kerana bersemangat tinggi, keberanian menghadapi musuh, berilmu, menjadi pelindung, setia, berketurunan baik, berpengaruh dan patuh pada yang berkuasa. Simbol jantan ayam sabungan juga sentiasa menjadi ingatan kepada masyarakat, seperti dalam prinsip Gagasan Kritikan Melayu, kritikan Melayu membawa contoh yang lebih baik. Jelas, konsep ayam sabungan yang dibincangkan di atas menjadi contoh yang positif kepada masyarakat seperti yang tergambar dalam Ungkapan Melayu.

\section{Simbol Jantan Positif dalam Kategori Sifat}

Simbol jantan positif yang dapat dilihat perkaitan antara lambang dengan sifat seseorang seperti yang disenaraikan dalam Jadual 1. Antaranya simbolnya termasuklah "jantan adil”, “jantan baik”, "jantan bijak”, jantan alim”, “jantan gagah”, "jantan jinak", "jantan licin", "jantan liat", "jantan tabah" dan "jantan lincah", "jantan cerdas", "jantan elok", "jantan halus", jantan sabar", "jantan yakin", "jantan laku", "jantan lurus", "jantan lasak", "jantan cerdik", "jantan faham" dan "jantan iba". Kategori sifat ini dapat dibahagikan pula kepada beberapa bahagian. Pertama, sahsiah seseorang itu terlihat pada sifat keperibadiannya yang baik, adil, lurus, alim, tabah, sabar, jinak, iba dan yakin. Kedua, tingkat sifat kepandaian. Seseorang itu dianggap memiliki ilmu dan tahu ilmu, sehingga menjadi faham, cerdik, cerdas 
dan bijak. Ketiga, kekuatan fizikal lelaki yang gagah, liat, licin, lincah, dan lasak. Kesemua "jantan" yang diberikan simbol kekuatan fizikal lelaki, iaitu gagah, liat, lincah, menunjukkan kekuatan fizikal, kuat bekerja dan tidak malas, berbudi elok, rajin dan baik akhir hidupnya. Keempat, barulah keterampilan lelaki yang elok, halus dan laku.

Prinsip dalam Gagasan Kritikan Melayu membawakan contoh yang lebih baik. Apabila dasar kritikan untuk menunjangi ilmu, maka keupayaan yang amat penting dalam kritikan ini mengemukakan hujah atau alasan yang lebih baik, sesuai dengan anjuran agama Islam untuk berdebat dengan ilmu yang lebih baik (Ariff, 2016). Simbol jantan dalam kategori sifat sahsiah seseorang itu terlihat pada sifat keperibadiannya yang baik, adil, lurus, alim, tabah, sabar, jinak, iba dan yakin. Sifatsifat tersebut memberikan contoh teladan yang baik kepada khalayak atau anggota masyarakatnya. Misalnya simbol ungkapan "jantan iba” yang merujuk sahsiah seseorang yang mudah berasa ihsan dan simpati terhadap penderitaan orang lain, menjadikannya sentiasa berbuat jasa dan beramal dengan amalan mulia, seperti contoh petikan di bawah;

Yang disebut "jantan iba":

budi elok harta pengiba

menengok yang susah hatinya hiba

menengok yang melarat hatinya duka

menolong orang tiada berkira

amalnya banyak berbuat pahala

hidup berguna, mati berjasa

(2012: 375)

Ungkapan "jantan iba" di atas mengingatkan anggota masyarakat supaya sentiasa menjaga keperibadian, agar menjadi contoh teladan yang lebih baik kepada generasi baharu, selaras dengan prinsip dalam Gagasan Kritikan Melayu yang menyebut karya kesusasteraan harus membawa contoh yang lebih baik kepada khalayak atau masyarakatnya. Kesan yang sama juga turut diperlihatkan melalui ungkapan seperti “jantan baik", "jantan adil”, “jantan lurus”, “jantan alim", “jantan tabah”, “jantan sabar", "jantan jinak" dan "jantan yakin” dan lain-lain.

Simbol jantan dalam kategori "sifat kepandaian" pula memaparkan makna tersirat tentang lelaki yang memiliki ilmu sehingga menjadi orang yang faham, cerdik, 
cerdas dan bijak. Gambaran tersebut selaras dengan prinsip kelima dalam Gagasan Kritikan Melayu yang menekankan faktor karya sastera dapat menyumbangkan ilmu kepada khalayak atau masyarakat. Oleh itu, perbincangan ini menunjukkan teks klasik Melayu telah menyerapkan budaya dan cita rasa Islam yang membawa kepada pemikiran akliah, dan bukan bersandarkan aspek seni semata-mata. Ungkapan Melayu tentang "jantan" turut mengungkapkan lambang ilmu yang perlu ada pada seseorang lelaki. Paparan sedemikian dapat dikesan pada ungkapan "jantan cerdas", "jantan cerdik" dan "jantan bijak" seperti yang diperlihatkan dalam contoh petikan di bawah:

\author{
Yang disebut "jantan cerdas": \\ ditunjuk diajar fahamnya lekas \\ mencontoh meneladan dapat sekilas \\ tahu menghitung hujan dan panas \\ fikiran tajam akal pun cerdas
}

(2012: 372)

Secara umumnya tahap kecerdasan fikiran manusia mengikut tahap tumbesarannya. Oleh itu, dalam konteks masyarakat zaman dahulu seseorang itu dapat dianggap cerdas sekiranya mudah memahami apa-apa yang diajar. Tahu menilik hujan dan panas mengandungi pengertian tersirat, iaitu tentang kepandaian menilai kebaikan dan keburukan. Dalam pandangan dunia masyarakat Melayu, segala fenomena alam dapat menentukan "pokok hari". Muhammad Haji Salleh (1992) menyatakan bahawa semua puisi tradisional seperti pantun, mantera, cerita-cerita, epistemologi asas membuktikan bahawa manusia Nusantara ini bukan sahaja penghuni alam yang setia tetapi juga perenung jagas yang sabar dan pintar. Berbagai-bagai jenis pepohonan, bunga-bungaan, binatang dan bentuk alam seperti gunung, bukit dan lembah, sungai, laut, angin dan bayu dilihat sebagai tanda untuk nasibnya, masa hadapannya, terutama dalam situasi kritis atau genting. Misalnya dalam sastera lisan, kedatangan raja atau orang ke rumah juga akan didahului dengan bunyi-bunyi ayam dan burung, yang nampaknya juga dapat membaca niat manusia dan oleh itu dipercayai juga sebagai pemberita dan pengingat. Sebagai contoh, ungkapan "jantan cerdas"; tahu menghitung hujan dan panas. Lelaki yang cerdas tahu membuat perhitungan bila akan turun hujan dan bilakah hari akan panas. Namun begitu, secara tersirat, maksud ungkapan itu merupakan tahu akan untung dan rugi atau tahu diri berada dalam keadaan terancam. Oleh itu, lelaki itu perlu sentiasa berjaga-jaga dan beringat-ingat. 
Menurut Tenas Effendy (2012, p.2), nilai asas budaya Melayu yang bersifat Islam menyatu dengan sifat alam semula jadi dan membentuk kearifan serta jati diri Melayu. Gambaran tersebut dapat dikesan pada Ungkapan Melayu tentang "jantan cerdik" yang berikut:

Yang disebut "jantan cerdik":

ditunjuk ajar hatinya celik

Memecahkan masalah tidaklah pelik

Fikiran luas akal pun cerdik

Sampai mati namanya baik

(2012: 372)

Ungkapan tentang sifat melalui simbol "jantan cerdik" di atas menjelaskan tentang seseorang yang sentiasa mahu menerima tunjuk ajar, terang hati, berfikiran luas dan pandai menghuraikan masalah ibarat "menarik rambut dalam tepung", Dengan memanfaatkan kebijaksanaan yang dimilikinya, membantu tindakan yang diambil pada saat-saat genting dan hasilnya berjaya menyelesaikan permasalahan dengan situasi "rambut tidak putus, tepung tidak berserak". Demikian antara kesan makna yang diperlihatkan melalui penggunaan simbol "jantan cerdik" yang dipaparkan dalam Ungkapan Melayu. Sementara Ungkapan "jantan bijak" pula memperlihatkan tahap kecerdasan akal yang lebih tinggi dan matang seperti yang dipaparkan dalam contoh petikan ungkapan yang berikut:

Yang disebut "jantan bijak":

budi elok laku pun bijak

Hati teguh ilmunya banyak

Iman tebal tiada berganjak

Hemat berhitung arif bertindak

Tahu di mana tempat berpijak

Tahu beban mengertikan hak

Tahu mengikut adat dan syarak

Tahu menyimpai mana yang retak

Tahu menentang musuh mencapak 
Mudanya elok tuanya tunak

Diteladani oleh orang banyak

Sampai mati tuahnya nampak

(2012: 372)

Berdasarkan ungkapan di atas, ilmu yang dimiliki seseorang akan menjadikannya lelaki yang digelar "jantan bijak". Seorang lelaki yang berbudi pekerti, beriman, teguh hati, dan membuat pertimbangan untuk membuat keputusan serta tindakan. "Jantan bijak" dipaparkan sebagai orang yang tahu di mana tempatnya berpijak. Lelaki yang digambarkan ini sedar kedudukannya dalam masyarakat. Oleh itu, sifatnya jelas tidak akan melanggar orang yang lebih berkuasa. Lelaki yang digelar "jantan bijak" juga tahu menghormati adat dan peraturan serta tidak melanggarnya. "Jantan bijak" ini tahu tanggungjawab dan menghormati hak diri serta orang lain. Segala perbuatannya bersendikan adat dan syarak. "Tahu menyimpai mana yang retak" dalam contoh petikan di atas membawa maksud kebijaksanaan seseorang dalam usaha menyelesaikan masalah supaya tidak berpanjangan. Ilmunya yang tinggi juga dimanfaatkan untuk menentang musuh kerana kepandaiannya mencari kelemahan musuh. Lelaki yang memiliki sifat ini akan berterusan dengan sifat tersebut sehingga ke hari tua.

Selain itu, bagi simbol Jantan dalam kategori sifat kekuatan fizikal pula merangkumi gambaran fizikal lelaki yang dipaparkan maknanya melalui penggunaan simbol seperti "jantan gagah", "jantan liat”, "jantan licin”. "jantan lincah" dan "jantan lasak". Misalnya untuk menggambarkan "jantan gagah" Ungkapan Melayu melukiskannya seperti paparan yang berikut:

Yang disebut "jantan gagah":

hati berani rupa pun gagah

hidup berbangsa eloklah tingkah

berkata lurus, bermuka ramah

fikiran panjang,akal semenggah

dalam bergaul suka merendah

menghadapi musuh pantang menyerah

bekerja tidak mengenal lelah 
iman teguh amal berlimpah

dunia akhirat hidupnya berkat

(2012, p.374)

Gambaran tentang sifat kekuatan fizikal di atas menunjukkan ungkapan “jantan” yang diberikan simbol kekuatan fizikal sebagai lelaki gagah. Tidak hanya gagah dari segi fizikal, malah simbol "jantan gagah" turut memiliki kelebihan lain seperti hati berani, elok tingkah, bermuka ramah, fikiran panjang, merendah diri, kuat bekerja, iman teguh, amal berlimpah, dan dunia akhirat hidupnya berkat. Dengan perkataan lain, ungkapan simbol "jantan gagah" membawa siratan makna yang cukup luas dan rencam. Malah, menjadi lelaki yang cukup sempurna serta menjadi sanjungan anggota masyarakat kerana sifat positif yang disandang oleh lelaki seperti itu dalam masyarakat.

Selain itu, simbol jantan dalam kategori sifat peribadi pula memaparkan lelaki yang dikatakan mempunyai keterampilan yang elok, dan halus tingkah laku seperti yang disimbolkan melalui ungkapan "jantan elok", “jantan laku”, “jantan halus", dan seumpamanya. Misalnya, melalui contoh ungkapan "jantan elok" melakarkan peribadi seseorang lelaki yang diharapkan oleh masyarakat, seperti yang dipaparkan melalui ungkapan berikut;

Yang disebut "jantan elok":

budi baik, perangai pun elok

Fikiran panjang akal tak suntuk

Melawan musuh pantanglah tunduk

Tegap berdiri sempurna duduk

(2012: 373)

Melalui contoh di atas, jelas memperlihatkan sifat peribadi positif yang harus ada pada diri seorang lelaki untuk mendapat penghormatan serta kedudukan tinggi dalam masyarakat. Dengan memiliki "budi baik", "perangai pun elok", "fikiran panjang" dan seumpamanya bermaksud lelaki yang menyandang status "jantan elok" mewakili sifat peribadi positif yang sering diungkapkan dalam bentuk karya kesusasteraan, termasuk dalam Ungkapan Melayu. Secara umumnya, simbol jantan positif yang dipaparkan dalam karya sastera, menekankan segi sifat dan sahsiah keperibadian seorang lelaki, penuh ilmu dunia dan akhirat, berbanding dengan keterampilan 
MELAYU: JURNAL ANTARABANGSA DUNIA MELAYU JILID 14 BIL. 1 JANUARI 2021

fizikalnya yang hanya indah pada pandangan. Namun begitu, sekiranya terdapat kedua-duanya, iaitu kekuatan sahsiah dan fizikal, maka itulah simbol jantan yang kukuh sifatnya.

\section{DAPATAN KAJIAN}

Melalui analisis teks, penggolongan jantan positif terhadap unsur sifat lebih banyak jumlahnya kerana secara langsung dapat menjelaskan maksud lambang jantan. Melalui prinsip kedua Gagasan Kritikan Melayu menunjukkan, perlambangan jantan menggunakan unsur benda dan perilaku bagi memaparkan imej tersirat yang mengungkapkan budaya, alam, kerohanian dan estetika. Dengan cara ini, teks memperlihatkan pemikiran masyarakat, kerana simbol benda yang digunakan amat dekat dengan persekitaran masyarakat Melayu, iaitu unsur alam, gelaran manusia dan benda. Berdasarkan prinsip ketiga gagasan pula menunjukkan perlakuan yang memberikan kesan baik kepada seorang lelaki dan masyarakat seluruhnya.

Simbol jantan positif yang mementingkan seseorang memiliki ilmu, memaparkan unsur tersirat melalui lambang-lambang yang memberikan ilmu kepada pembaca. Dapatan menunjukkan lambang jantan banyak menggunakan sikap dan perilaku lelaki. Perilaku dan sikap jantan yang "patut" diserlahkan dalam Ungkapan Melayu menunjukkan perlakuan yang memberikan kesan baik kepada masyarakat dalam bentuk pengajaran, nasihat dan nilai mulia sebagai pedoman. Sekali gus sejajar dengan prinsip keempat dalam Gagasan Kritikan Melayu, iaitu untuk menimbulkan kesedaran dan memberikan pengajaran serta memberi contoh yang baik kepada masyarakat.

Selain itu, ungkapan tentang jantan positif menyentuh unsur kerohanian, iaitu kehidupan sesudah mati. Dalam pemikiran masyarakat, pemakaian ungkapan Melayu "jantan", segala tindakan dan sikap jantan semasa hidupnya akan memberikan kesan semasa hidup dan juga selepas mati. Hal ini berkait rapat dengan ajaran agama Islam yang mementingkan kebaikan semasa hayat untuk menikmati pengakhiran yang indah di alam akhirat. Penemuan ini sejajar pula dengan Gagasan Kritikan Melayu ketujuh yang menyentuh soal kebatinan dan kerohanian. Ungkapan tentang jantan positif turut meneliti imaginasi sejajar dengan prinsip kelapan Gagasan Kritikan Melayu. Segala lambang yang berkaitan dengan sesuatu yang abstrak membangkitkan imaginasi sekali gus dapat dikaitkan dengan cerita rakyat, kepercayaan masyarakat dan sebagainya.

Ungkapan Melayu terbukti memaparkan estetika berbahasa, melalui penggunaan bahasa berirama dan terikat pada bentuk, selain estetika unsur pada pilihan perkataan 
dalam ungkapan Melayu itu. Selain itu, banyak lambang jantan yang dibincangkan juga memperlihatkan cara seseorang lelaki itu berbahasa boleh memberikan kesan terhadap dirinya, keluarga dan masyarakat. Dapat dilihat bahawa masyarakat mementingkan kesantunan berbahasa dalam perhubungan hidup bermasyarakat. Dalam keindahan bahasa Ungkapan Melayu, terpapar nilai intelektual kearifan masyarakat yang tinggi, seperti yang digagaskan dalam prinsip kesembilan, iaitu kritikan mementingkan pengucapan bahasa yang halus dan penuh estetika, di samping turut menerangkan prinsip kesepuluh gagasan, iaitu karya sastera Melayu itu bersifat intelektual. Melalui prinsip terakhir Gagasan Kritikan Melayu berupaya menyelongkar konsep pemikiran masyarakat tentang ungkapan Melayu yang antara lain turut dikaitkan dengan unsur-unsur yang menjadi pegangan orang Melayu-Islam seperti Sifat 25, pantangan 25 dan seumpamanya.

\section{KESIMPULAN}

Penelitian terhadap Ungkapan Melayu - Pemahaman dan Permasalahannya memfokuskan hanya pada simbol jantan positif. Perbincangan bersandarkan Gagasan Kritikan Melayu oleh S. Othman Kelantan yang mengandungi sepuluh gagasan prinsip terhadap simbol jantan positif. Dapat dirumuskan bahawa sejumlah 52 Ungkapan Melayu tentang jantan positif dalam teks menepati semua prinsip dalam Gagasan Kritikan Melayu.

Ungkapan Melayu ternyata berupaya menjadi bahan kritikan, panduan dan pedoman kepada masyarakatnya. Kajian tentang jantan positif dalam Ungkapan Melayu menganalisis pandangan dunia masyarakat Melayu dalam sastera lisan, di samping maksud tersurat dan tersirat melalui penggunaan lambang. Jantan positif dalam analisis data telah dikategorikan kepada benda, perilaku, konsep dan sifat/ sahsiah. Secara ringkasnya jantan positif dalam Ungkapan Melayu memberikan panduan kepada manusia lelaki Melayu agar memiliki perilaku dan sahsiah terpuji yang akhirnya membawa manfaat kepada diri, keluarga dan masyarakatnya, untuk kebahagiaan dunia dan akhirat.

\section{NOTA}

1 https://www.facebook.com/mis3NHA/posts/10153028877212158 


\section{RUJUKAN}

Amril Shah. (2000). Siri jenaka gembira: Pak Kaduk dengan ayam jaguh. Selangor Petaling Jaya: SAMA Publications \& Distributors Sdn Bhd.

Ariff Mohamad. (2016). Makna Siratan dalam Novel Politik Melayu Terpilih: Analisis Berdasarkan Gagasan Kritikan Melayu (Tesis Ph.D. tidak diterbitkan). Akademi Pengajian Melayu, Universiti Malaya.

Hairudin Harun. (2001). Kosmologi Melayu dalam era teknologi maklumat. Kuala Lumpur: Dewan Bahasa dan Pustaka.

Muhammad AriffAhmad. (2004). Mari Kita Berpantun (Suatu Petunjuk). Singapura: MBMS

Muhammad Haji Salleh. (1992). Puitika sastera Melayu: Suatu pertimbangan. Bangi: Universiti Kebangsaan Malaysia.

Muhammad Haji Salleh. (2006). Puitika sastera Melayu. Kuala Lumpur: Dewan Bahasa dan Pustaka.

Rizal Abu Bakar. (2019, Jun). Pakar dedah menurut WHO, betik diangkat raja buah sebenar! Mingguan Wanita. Diakses daripada https://mingguanwanita.my/pakar-dedahmenurut-who-betik-diangkat-raja-buah-sebenar/

S. Othman Kelantan. (1997). Pemikiran satira dalam novel Melayu. Kuala Lumpur: Dewan Bahasa dan Pustaka

S. Othman Kelantan, (1998). Kertas Kerja Pidato Karyawan Tamu "Kritikan Sastera." Universiti Malaya: Kuala Lumpur.

Tenas Effendy, (1989). Ungkapan Tradisional Melayu Riau. Kuala Lumpur: Dewan Bahasa dan Pustaka.

Tenas Effendy. (1994). Tunjuk ajar Melayu: Butir-butir budaya Melayu Riau. Pekan Baru: Pemda Riau.

Tenas Effendy. (2012). Ungkapan Melayu: Pemahaman dan masalahnya. Singapura: Kesatuan Guru-Guru Melayu Singapura.

Tarikh Peroleh (received): 23 Julai 2020

Tarikh Terima (accepted): 08 Disember 2020 